\title{
RESEARCH
}

Open Access

\section{Chromosome 17p13 deletion is associated with an aggressive tumor phenotype in clear cell renal cell carcinoma}

Till Eichenauer ${ }^{2}$, Navid Shadanpour ${ }^{1}$, Martina Kluth ${ }^{1}$, Cosima Göbel', Sören Weidemann ${ }^{1}$, Christoph Fraune ${ }^{1}$, Franziska Büscheck', Claudia Hube-Magg ${ }^{1}$, Christina Möller-Koop ${ }^{1}$, Roland Dahlem², Margit Fisch², Michael Rink², Silke Riechardt ${ }^{2}$, Eike Burandt ${ }^{1}$, Christian Bernreuther ${ }^{1}$, Sarah Minner ${ }^{1}$, Ronald Simon ${ }^{1 *}$, Guido Sauter ${ }^{1}$,

Waldemar Wilczak ${ }^{1}$ and Till Clauditz ${ }^{1}$

\begin{abstract}
Background: Deletions of 17p13 recurrently occur in renal cell carcinoma (RCC) but their prognostic role seems to be uncertain.

Methods: To determine prevalence, relationship with tumor phenotype, and patient prognosis, a tissue microarray containing samples from 1809 RCCs was evaluated using dual labeling fluorescence in situ hybridization (FISH) with $17 \mathrm{p} 13$ and chromosome 17 centromere probes.

Results: A 17p13 deletion was found in 72 of 1429 interpretable tumors. The frequency of 17p13 deletions varied greatly between RCC subtypes and was highest in chromophobe RCC (24/72; 33.3\%). 17p13 deletions were also found in 35 (3.7\%) of 946 clear cell RCC, 9 (4.3\%) of 208 papillary RCC, 1 of 121 oncocytomas (0.8\%), as well as in several rare cases of comprising 1 of 7 Xp11.2 translocation cancers, 1 of 3 collecting duct carcinomas, and 1 of 20 not otherwise specified (NOS) carcinomas. In clear cell carcinomas, 17p13 deletions revealed a strong and consistent association with higher Fuhrman, ISUP, and Thoenes grade ( $p<0.0001$ each), and linked to advanced tumor stage $(p=0.0168)$, large tumor diameter $(p=0.0004)$, distant metastases $(p=0.0077)$, cancer-specific survival ( $p=0.0391)$, and recurrence-free survival $(p=0.0072)$. In multivariate analysis, 17p13 deletions showed in clear cell RCC a dependent prognostic role for established clinical-pathological parameters.
\end{abstract}

Conclusion: 17p13 deletions have a dual role in RCC. They are associated with disease progression in clear cell RCC and possibly other subtypes and they are linked to the development of chromophobe RCC - a subtype with a particularly favorable prognosis.

Keywords: Renal cell cancer, 17p13 deletion, Fluorescence in situ hybridization, Tissue microarray, Prognosis

\footnotetext{
* Correspondence: R.Simon@uke.de

${ }^{1}$ Institute of Pathology, University Medical Center Hamburg-Eppendorf,

Martinistr. 52, 20246 Hamburg, Germany

Full list of author information is available at the end of the article
}

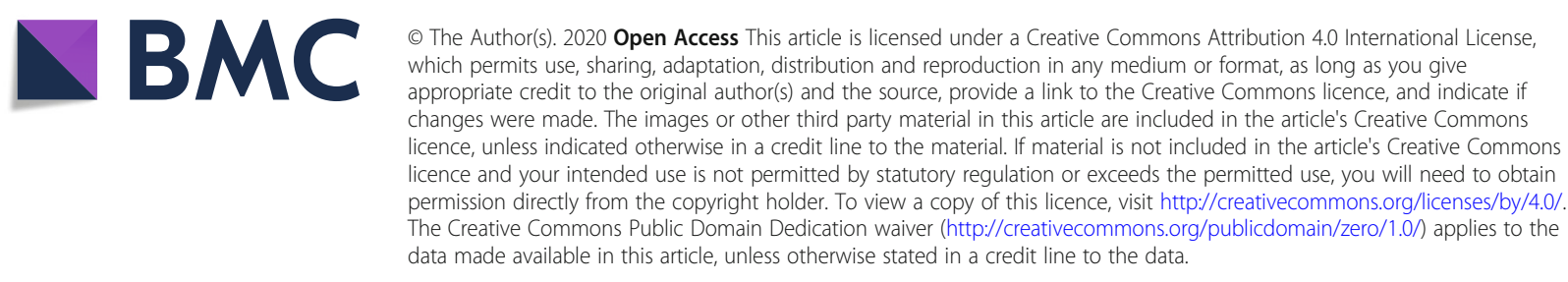




\section{Introduction}

Renal cell carcinoma (RCC) is the 9th most common tumor worldwide [1]. Its incidence is rising and is highest in countries with high socio-economic status [2]. The reasons behind the growing incidence, especially in developing countries, are a persistently increasing impact of risk factors like smoking, obesity, hypertension, and increasing patient age, but also a more frequent use of common medical imaging types like ultrasound, computer-tomography, and magnetic resonance imaging [3] which lead to an earlier diagnosis. The latter is a likely reason for a reduction of mortality in many countries over the past decade [2].

Localized RCC treatment is generally achieved through radical or partial nephrectomy. Even in metastatic disease, a surgical approach plays a major role if metastases are resectable. Renal cell carcinomas are often resistant to radiation and to most chemotherapies [4]. However, several new drugs such as sunitinib or immunecheckpoint inhibitors have recently yielded better results $[5,6]$. Currently, it is thus being evaluated in clinical trials, whether an adjuvant application of these new drugs can improve the prognosis of patients at high risk for disease recurrence or progression after nephrectomy (Keynote-564, iMmotion010, Checkmate-914). Sunitinib was approved by the FDA for this purpose in November 2017. If adjuvant treatment becomes a standard of care, risk stratification will become more important than ever before, to find out which patient is at risk and might benefit from adjuvant therapies. The increasing knowledge about the cell biology of RCC might eventually lead to the identification of molecular tumor features that might help to improve risk stratification.

Chromosomal deletions are often found in many cancers including kidney cancer [7]. In many tumor types, chromosomal deletions were found to be highly prognostic [8-12]. Deletion analysis appears to be particularly well suited for clinical applications and as they are easily detectable by fluorescence in situ hybridization (FISH) resulting in a reproducible yes/no answer (deletion present or not present). The short arm of chromosome $17(17 \mathrm{p})$ has also been described to be recurrently deleted in kidney cancers, mainly in the chromophobe subtype [13-16]. The prognostic role of 17p13 deletions in RCC is currently unknown, however.

To learn more about the diagnostic and prognostic role of $17 \mathrm{p} 13$ deletions in RCC, we thus evaluated more than 1800 kidney tumors-many of which with attached followup data-in a tissue microarray (TMA) format by FISH.

\section{Materials and methods}

\section{Patients}

The kidney tumor TMA utilized in this study included samples collected from 1809 patients who underwent surgery at the Institute of Pathology of the University
Medical Center Hamburg-Eppendorf (UKE), Germany, between 1994 and 2016. All tumors have been histologically reviewed by two pathologists expertized in genitourinary pathology $(\mathrm{FB}, \mathrm{CF})$ at the Institute of Pathology (UKE) following WHO 2016 classification [17]. The International Society of Urological Pathology (ISUP) grading has been applied to each tumor. The TMA consists of four blocks, including one that was built earlier [18]. The TMA construction has been previously described [19]. Supplementary Table 1 summarizes the clinical and pathological parameters of the evaluated cancers. In this report, the mean follow-up period was 48 months. Local laws (HmbKHG, \$12,1) and the local ethics committee (Ethics Commission Hamburg, WF-049/09) approved the use of archived diagnostic left-over tissues for the analysis of TMA construction for research purposes as well as the analysis of patient data. All work has been carried out in accordance with the Helsinki Declaration.

\section{Fluorescence in situ hybridization (FISH)}

The general FISH protocol was carried out as described before [20]. The probe set included a spectrum-green labeled $17 \mathrm{p} 13$ (targeting the TP53 gene locus) probe (BACs RP11-89D11, RP11-404G1; Source Bioscience, Nottingham, UK), and a commercial spectrum-orange-labeled centromere 17 reference probe (\#06)36-017; Abbott, Chicago, USA).In our evaluation, we excluded tissue spots (tumor or normal cells) without green $17 q 13$ signals or any normal cells as an internal control for successful FISH probe hybridization. For each tissue spot, the predominant FISH signal numbers were recorded. Lack of green signal in $\geq 60 \%$ of tumor nuclei indicated homozygous $17 q 13$ deletion, whereas a reduced number of $17 \mathrm{p} 13$ probe signals compared to the centromeric 17 probe in $\geq 60 \%$ of tumor nuclei indicated heterozygous $17 q 13$ deletion. Thresholds were selected on the basis of the previous study on PTEN deletion results obtained by FISH and single-nucleotide polymorphism (SNP) in a cohort of prostate cancers [21].

\section{Statistics}

The software JMP 12 (SAS Institute Inc., NC, USA) was used for statistical calculations. Contingency tables and the Chi-square test were used to study associations between $17 \mathrm{p} 13$ deletions and tumor phenotype. Survival curves were generated using the Kaplan-Meier method and significant survival differences between groups were estimated using the log-rank test. Cox proportional hazards regression analysis was carried out to verify the differences in data for significant associations between pT, ISUP grade, and $17 \mathrm{p} 13$ deletions. 


\section{Results}

\section{Technical issues}

In total, 1429 out of 1809 (79\%) tissue spots provided comprehensive data. Reasons for non-informative cases (380 spots; 21\%) included insufficient hybridization with absence of clear $17 \mathrm{p} 13$ and/or centromere 17 signals, missing tissue spots, or unclear presence of a cancer tissue on the TMA spot.

\section{$17 p 13$ deletion in renal cell cancer}

Representative images of cancers with and without 17 p13 deletion are shown in Fig. 1. A total of 72 out of 1429 analyzable tumor samples (5\%) featured $17 \mathrm{p} 13$ deletions. The frequency of $17 \mathrm{p} 13$ deletions was markedly higher in chromophobe carcinomas $(24 / 72,33.3 \%)$ as compared to clear cell RCC (35/946, 3.7\%) and papillary RCC (9/208, 4.3\%). 17p13 deletion was present in only one oncocytoma $(1 / 121,0.8 \%)$ and was not seen in 24 clear cell tubulo-papillary RCCs (Table 1). 17p13 deletion was also found in rare subtypes such as in collecting duct carcinomas $(1 / 3,33 \%), \mathrm{Xp} 11.2$ translocation RCC $(1 / 7,14 \%)$, and in not otherwise specified tumors $(1 / 20$, $5 \%$ ) (Table 1). In clear cell RCC, 17p13 deletions were strongly linked to ISUP, Fuhrman, and Thoenes grade $(p$ $<0.0001$ each); pT stage $(p=0.0168)$; and presence of distant metastases ( $M$ stage, $p=0.0077$; Table 2). Clear cell RCC with 17p13 deletions were significantly larger than those without deletions $(p=0.0004$, Table 3$)$. In papillary and chromophobe RCC, 17 p13 deletions were unrelated to tumor phenotype (data not shown) and tumor diameter (Table 3).

\section{Associations with patient survival}

In the present study, follow-up data for 789 clear cell and 177 papillary cancers were accessible. Figure 2a, b shows associations between ISUP grade and tumor stage with the survival data for our clear cell cancers. These findings demonstrate the validity of our follow-up data. 17 p13 deletions were significantly associated with progression-free survival in the joint analysis of all tumors $(p=0.0411)$. Also, in the largest subgroup of clear cell cancers, $17 \mathrm{p} 13$ deletions were significantly associated with shortened cancer-specific $(p=0.0391)$ and recurrence-free $(p=0.0072)$ survival. $17 \mathrm{p} 13$ deletions were unrelated to patient prognosis in papillary cancers, probably due to the small minority of cases with 17 p13 deletion. All data are shown in Fig. 3. Followup data were insufficient (only 73 patients with follow-up information) to analyze the prognostic role of $17 \mathrm{p} 13$ deletions in chromophobe carcinomas. In a multivariate analysis including $\mathrm{pT}, \mathrm{pN}, \mathrm{M}$ status, and ISUP grade, $17 \mathrm{p} 13$ deletions did not show an independent prognostic significance for all endpoints (supplement table 2).

\section{Discussion}

The results of this study identify a dual role of $17 \mathrm{p} 13$ deletions in RCC. These deletions are involved in the

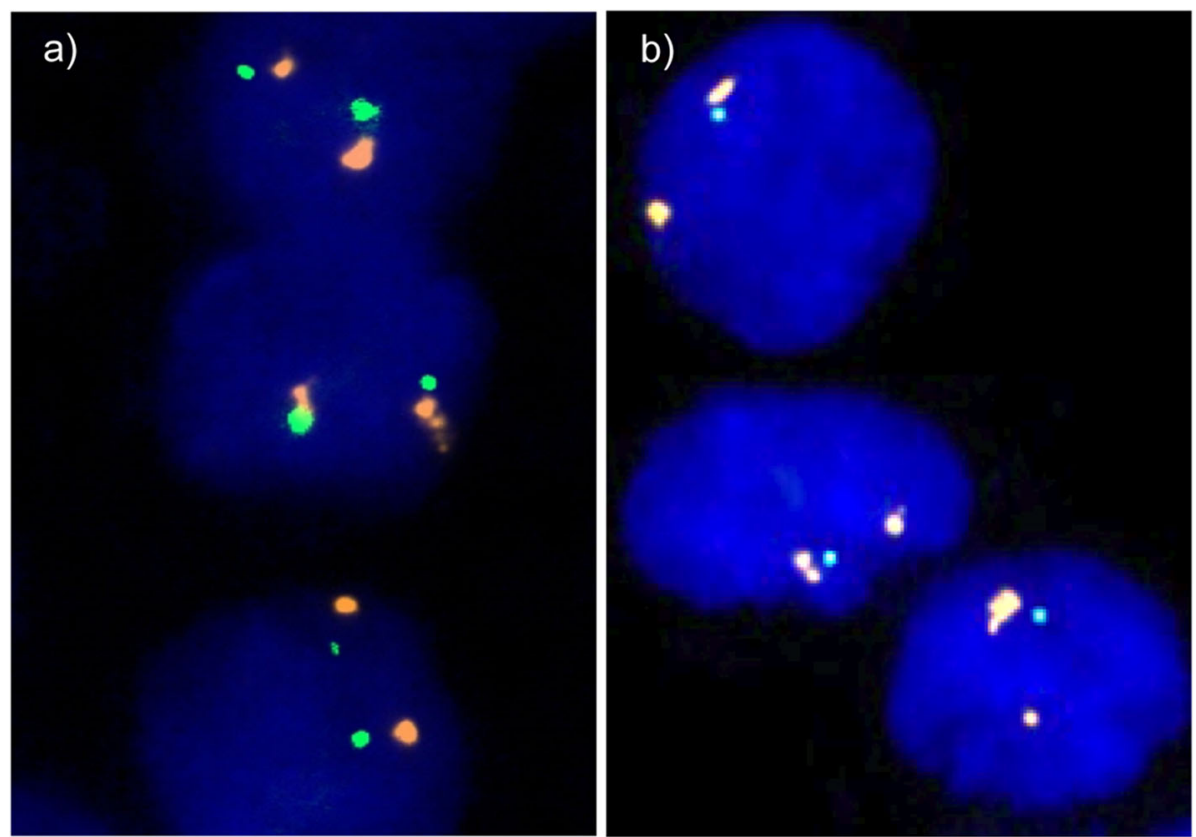

Fig. 1 Representative images of FISH analysis. a Normal 17p13 copy numbers as indicated by two green 17p13 signals and two orange centromeres 17 signals and $\mathbf{b}$ heterozygous deletion as indicated by the lack of one green 17p13 signal 
Table 1 Prevalence of 17p13 deletions in different histological subtypes of renal cell tumors

\begin{tabular}{lll}
\hline Renal cell tumor type & Analyzable $(\boldsymbol{n})$ & $17 p$ deletion (\%) \\
\hline Clear cell renal cell carcinoma & 976 & 3.7 \\
Papillary renal cell carcinoma & 208 & 4.3 \\
Oncocytoma & 121 & 0.8 \\
Chromophobe renal cell carcinoma & 72 & 33 \\
Clear cell (tubulo) papillary renal cell carcinoma & 24 & 0.0 \\
Carcinoma NoS & 20 & 5.0 \\
Nephroblastoma & 14 & 0.0 \\
Xp11.2 translocation renal cell carcinoma & 7 & 14 \\
Collecting duct carcinoma & 3 & 33 \\
Multilocular cystic clear cell renal cell neoplasm of low malignancy & 2 & 0.0 \\
Metanephric adenoma & 2 & 0.0 \\
Tubulocystic renal cell carcinoma & 2 & 0.0 \\
Mucinous tubular and spindle cell carcinoma & 2 & 0.0 \\
Acquired cystic disease-associated renal cell carcinoma & 1 & 0.0 \\
Cystic nephroma/mixed epithelial stroma tumor & 1 & 0.0 \\
Medullary carcinoma & 1 & 0.0 \\
Neuroendocrine carcinoma & 1 & 0.0 \\
Reninoma & 1 & 0.0
\end{tabular}

progression of clear cell and possibly other RCCs. They are also relevant for the development of chromophobe RCC, a less aggressive kidney cancer subtype.

The fraction of 17p13-deleted clear cell RCCs was $5 \%$ in our FISH analysis. A lower percentage than in most earlier studies, which described $17 \mathrm{p}$ deletions in $7-11 \%$ by classical comparative genomic hybridization (CGH) [22, 23], 4-77\% by loss of heterozygosity (LOH) analysis [24-40], 20\% by restriction fragment length polymorphism (RFLP) analysis [30, 41], 31$53 \%$ by single-nucleotide polymorphism (SNP) array hybridization [42, 43], $12 \%$ by classical cytogenetics [44], and 18\% using FISH [45]. Next-generation sequencing data available from The Cancer Genome Atlas (TCGA) [7] show 17p13 (TP53) deletions in 8\% of 345 analyzed clear cell RCC. It appears obvious that these differences in the frequency of reported $17 \mathrm{p}$ deletions are at least partly connected to technical issues related to the different methods. $\mathrm{LOH}$, CGH, RFNP, SNP, and NGS share the disadvantage that the analysis is performed on isolated DNA, which always bears the risk of DNA contamination from adjacent non-neoplastic cells such as stroma, immune cells, blood vessels, and so on. In addition, most studies used less sensitive methods than this study. FISH is considered the gold standard for detection of deletions. FISH allows a precise cell by cell assessment of the copy number of genomic regions of interest. FISH is independent of the presence and quantity of inflammatory or stroma cells. Some "false deletions" can be assumed in FISH analyses because some signals are always missing due to truncated cell nuclei that are incompletely represented on a tissue slide measuring only $3-4 \mu \mathrm{m}$ in thickness. A rigorous cutoff of $60 \%$ of tumor cells having less $17 \mathrm{p} 13$ than centromere 17 signals was thus selected in this project to define 17p13-deleted tumors. This is based on the assumption that clinically relevant intratumoral heterogeneity will not occur in a TMA spot measuring $0.6 \mathrm{~mm}$ in diameter. In an earlier study, we had found a $100 \%$ concordance between FISH and array $\mathrm{CGH}$ data for identifying PTEN deletions using this definition for deletion [21].

17 p13 deletions were clearly associated with an unfavorable tumor phenotype and poor prognosis in clear cell RCC. Given the striking association of 17 p13 deletions with tumor grade and stage, it is possible that the rather low number of 17p13-deleted cases in our study is due to the consecutive nature of our cohort including a large number of pT1 tumors. Considering the low frequency of 17 p13 deletions and the low number of papillary carcinomas in this study, it is not surprising that clear-cut associations between 17 p13 deletions and unfavorable tumor features could not be found in this RCC subtype. The significant link between 17 p13 deletions and progression-free survival would be consistent, however, with 17p13 deletions representing a universal feature of disease 
Table 2 Associations between 17p13 deletions and pathological parameters of clear cell renal cell carcinomas

\begin{tabular}{|c|c|c|c|}
\hline & \multicolumn{3}{|c|}{ Clear cell carcinomas } \\
\hline & Analyzable $(\boldsymbol{n})$ & 17p deletion & $\boldsymbol{p}$ value \\
\hline All & 976 & 3.7 & \\
\hline \multicolumn{4}{|l|}{ UICC } \\
\hline I & 420 & 1.9 & 0.0524 \\
\hline$\|$ & 74 & 5.4 & \\
\hline III & 116 & 4.3 & \\
\hline IV & 97 & 7.2 & \\
\hline \multicolumn{4}{|l|}{ ISUP } \\
\hline 1 & 257 & 1.5 & $<0.0001$ \\
\hline 2 & 316 & 1.9 & \\
\hline 3 & 305 & 5.3 & \\
\hline 4 & 60 & 15.0 & \\
\hline \multicolumn{4}{|c|}{ Fuhrman } \\
\hline 1 & 47 & 0.0 & $<0.0001$ \\
\hline 2 & 522 & 1.5 & \\
\hline 3 & 307 & 4.9 & \\
\hline 4 & 69 & 17.0 & \\
\hline \multicolumn{4}{|l|}{ Thoenes } \\
\hline 1 & 323 & 1.2 & $<0.0001$ \\
\hline 2 & 506 & 3.2 & \\
\hline 3 & 116 & 13.0 & \\
\hline \multicolumn{4}{|c|}{ Tumor stage } \\
\hline pT1 & 568 & 2.3 & 0.0168 \\
\hline pT2 & 118 & 5.1 & \\
\hline pT3-4 & 255 & 6.3 & \\
\hline \multicolumn{4}{|c|}{ Lymph node metastasis } \\
\hline pNO & 132 & 2.3 & 0.6416 \\
\hline pN1 & 8 & 0.0 & \\
\hline $\mathrm{pN} 2$ & 19 & 5.3 & \\
\hline \multicolumn{4}{|c|}{ Distant metastasis } \\
\hline $\mathrm{pMO}$ & 125 & 0.8 & 0.0077 \\
\hline $\mathrm{pM} 1$ & 95 & 7.4 & \\
\hline
\end{tabular}

progression in RCCs derived from the proximal tubule. The tumor suppressor p53 residing on chromosome $17 \mathrm{p} 13$ is an apparent candidate target gene of 17 p13 deletions. An altered p53 function occurs in less than $5 \%$ of clear cell and papillary RCCs [46]. Data from The Cancer Genome Atlas (TCGA) PanCancer database show concomitant p53 mutations only in 4 of 27 clear cell RCCs with $17 \mathrm{p} 13$ deletions [7]. It is possible, however, that a reduced p53 function in 17p13-deleted cells contributes to increased potential for further progression.
Table 3 Role of 17p13 deletions for tumor size in clear cell renal cell carcinomas

\begin{tabular}{lllll}
\hline & $17 p$ & $n$ & \multicolumn{2}{l}{ Tumor size $(\mathrm{cm})$} \\
\cline { 4 - 5 } & status & & Mean $\pm \mathrm{sd}$ & $p$ value \\
\hline All tumors & Normal & 1333 & $5.1 \pm 0.1$ & 0.0046 \\
& Deletion & 71 & $6.2 \pm 0.4$ & \\
Clear cell RCC & Normal & 898 & $5.3 \pm 0.1$ & 0.0004 \\
& Deletion & 34 & $7.1 \pm 0.5$ & \\
Papillary RCC & Normal & 194 & $5.1 \pm 0.3$ & 0.4142 \\
& Deletion & 9 & $6.1 \pm 1.2$ & \\
Chromophobe RCC & Normal & 47 & $5.0 \pm 0.4$ & 0.8695 \\
& Deletion & 24 & $5.1 \pm 0.6$ & \\
\hline
\end{tabular}

A large number of candidate prognostic markers have been suggested for kidney cancer in the past. These include deletions of chromosomal material such as losses of $1 \mathrm{p}, 3 \mathrm{p}, 8 \mathrm{p}, 9 \mathrm{p}$, and $14 \mathrm{q}$ in clear cell cancers [47-52], 3p, and X-chromosome loss in papillary cancers $[53,54]$, and monosomies of chromosome 1, 2, 10, 13, 17, and 21 in chromophobe RCC [55]. However, none of these markers was so far strong enough to compete with classical histo-pathological prognostic parameters in multivariable analyses. As a consequence, no molecular marker has entered routine clinical diagnostic procedures so far. Nevertheless, these abovementioned findings suggest that genomic instability is typically related with adverse renal cell cancer phenotype. It is, therefore, well possible that combinations of multiple genomic deletions may better predict the clinical course than one of these deletions alone. This is supported by studies showing that combinations of multiple deletions such as $3 p$ and 14q [47] or ploidy changes [56] are particularly strongly linked to poor prognosis. Future molecular prognostic test may, therefore, combine multiple genomic alterations. Although the $17 \mathrm{p}$ deletion did not show independent prognostic value in this study, it may be a valuable marker to be included in such potential future multiparametric tests, particularly for clear cell RCC.

That $17 \mathrm{p} 13$ deletions were strongly linked to chromophobe tumor subtype in this study fits well with data from earlier studies. As seen for clear cell RCCs, other investigators had earlier described even higher frequencies of $17 \mathrm{p} 13$ deletions in chromophobe cancers than the $33 \%$ in our study. Speicher et al. found a chromosome 17 loss in $13 / 17$ cases of chromophobe RCC using CGH [13]. Yusenko et al. found $17 \mathrm{p} 13$ deletions in $90 \%$ of 30 chromophobe RCC using SNP array analysis [15]. Nagy et al. 
a)

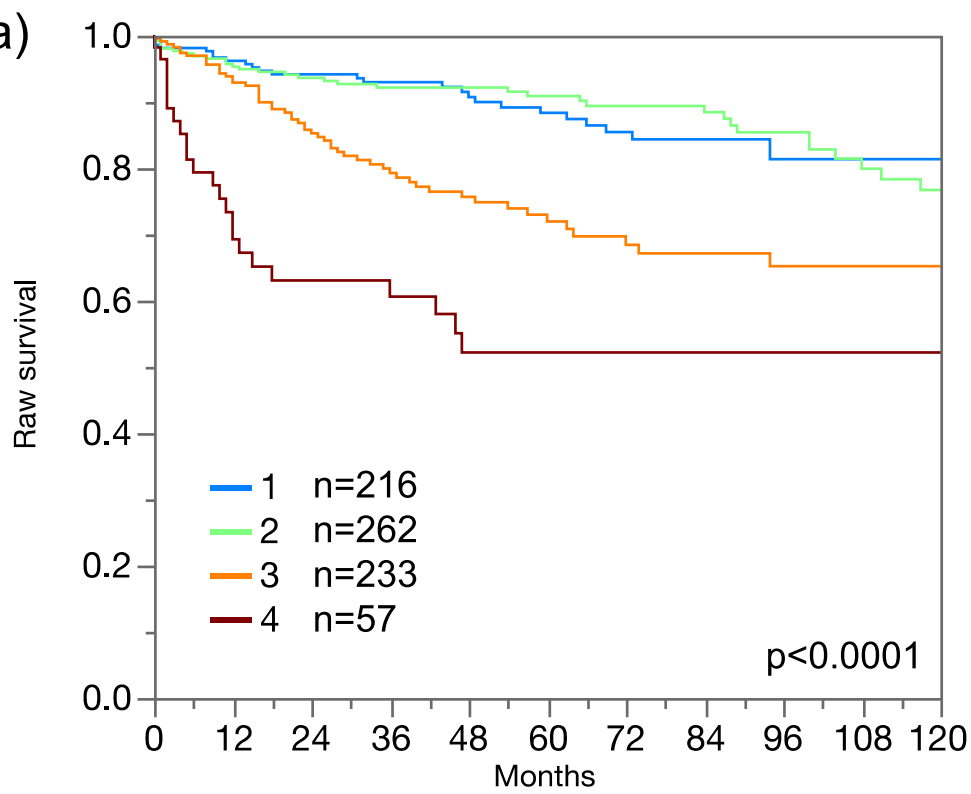

b)

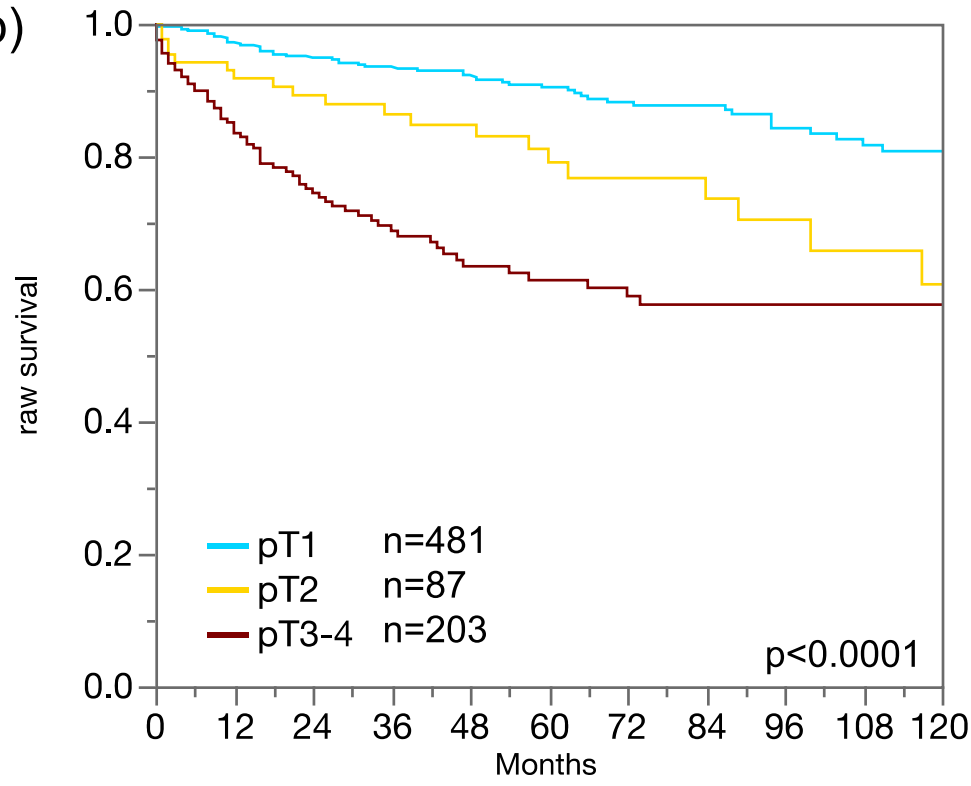

Fig. 2 Prognostic relevance of a ISUP grade and $\mathbf{b}$ tumor stage in clear cell renal cell carcinomas

described LOH in $90 \%$ of 21 chromophobe RCC by microsatellite allelotyping [16]. Brunelli et al. found 17 p13 deletions in 9 of 11 chromophobe cancers by FISH [14]. The TCGA database identified $17 \mathrm{p} 13$ deletions in $75 \%$ of 65 analyzed chromophobe RCCs [7]. The clinical outcome of chromophobe RCC is generally better than seen in clear cell RCC. It is thus unlikely, that the particular role of $17 \mathrm{p} 13$ deletions in these tumors is related to the TP53 gene, inactivation of which is generally associated with aggressive cancer [46].
Increasing evidence suggests that the association of $17 \mathrm{p} 13$ deletions with chromophobe RCC subtype may be driven by the Folliculin (FLCN) gene on 17p11.2. FLCN interacts with TFE3 and the Wnt pathway and plays a critical role for the exit from human pluripotency [57]. FLCN germline mutations cause the Birt-Hogg-Dubé (BHD) syndrome characterized by benign hair follicle hamartomas, spontaneous pneumothorax, lung cysts, and an increased risk for renal carcinoma. Patients with BHD syndrome tend to develop RCC, which primarily are chromophobe RCC (34\%) or renal hybrid oncocytic/chromophobe tumors 


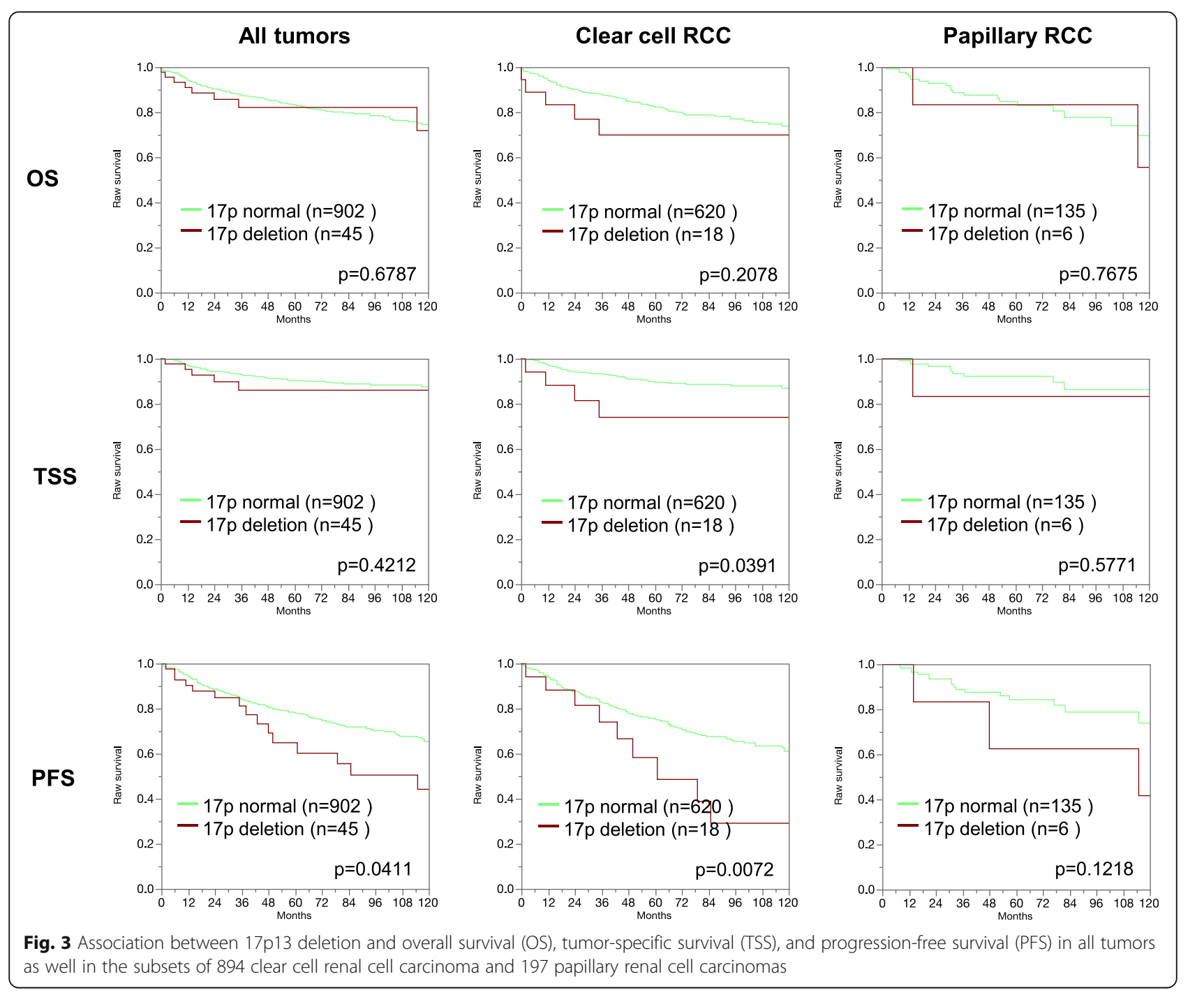

(50\%) with areas reminiscent of chromophobe RCC and oncocytoma [58]. According to the cBioPortal database [7], FLCN mutations were not found in 65 chromophobe carcinomas that had been sequenced in the TCGA project [7]. This suggests that the rare BHD syndrome is only linked to a small fraction of chromophobe RCCs. Based on all these data, it is tempting to speculate, that partial inactivation of FLCN in 17p13-deleted cells from the distal tubule favors the development of chromophobe cancers. It is of note that $17 \mathrm{p} 13$ deletions were exceptionally rare $(0.8 \%$ deleted cancers) in oncocytomas. Oncocytomas, the benign counterpart of chromophobe carcinoma, share the origin from the distal tubule with chromophobe carcinoma but are very uncommon in BHD syndrome. Given the tight link of $17 \mathrm{p} 13$ deletion and chromophobe RCC, one might assume that an additional loss of $17 \mathrm{p} 13$ occurring in an oncocytoma could result in a progression to renal hybrid oncocytic/chromophobe tumors, the most common RCC in BHD syndrome.

\section{Conclusion}

In summary, our data provide evidence for a dual role of $17 \mathrm{p} 13$ deletions in RCC. In cells from the distal tubule, $17 \mathrm{p} 13$ deletions contribute to the development of chromophobe RCC. In clear cell and papillary RCC derived from the proximal tubule, they are linked to disease progression. Together with other molecular parameters, the assessment of $17 \mathrm{p} 13$ deletions may have clinical utility for prognosis assessment in clear cell RCC and perhaps also papillary RCC.

\section{Supplementary information}

Supplementary information accompanies this paper at https://doi.org/10. 1186/s12957-020-01902-y.

\section{Additional file 1: Table S1. Pathological and clinical data of the} arrayed renal cell tumors.

Additional file 2: Table S2. Multivariate analysis in clear cell renal cell cancers using the endpoints overall survival (OS), tumor specific survival (TSS) and progression-free survival (TFS). 


\section{Abbreviations}

RCC: Renal cell carcinoma; FISH: Fluorescence in situ hybridization; NOS: Not otherwise specific; FDA: Food and Drug Administration; TMA: Tissue microarray; UKE: University Medical Center Hamburg-Eppendorf; WHO: World Health Organization; ISUP: International Society of Urological Pathology; PTEN: Phosphatase and tensin homolog; SNP: Single-nucleotide polymorphism; CGH: Comparative genomic hybridization; LOH: Loss of heterozygosity; RFLP: Restriction fragment length polymorphism; TCGA: The Cancer Genome Atlas; BHD: Birt-Hogg-Dubé

\section{Acknowledgements}

We are grateful to Inge Brandt, Sünje Seekamp, Melanie Witt, Maren Eisenberg, Sylvia Schnöger, and Sascha Eghteshadi for excellent technical assistance.

\section{Authors' contributions}

TE, CF, RS, MK, SM, CB, TC, and CHM contributed to conception, design, data collection, data analysis, and manuscript writing. NS, MK, FB, and EB to fish analysis. SW, RD, TE, MR, and SR to conception and design and collection of samples. DH, FJ, CG, CMK, and KK to collection and data analysis. MF, WW, GS, and TC to study supervision. The author(s) read and approved the final manuscript.

\section{Funding}

No funding was received

\section{Availability of data and materials}

Data will be made available upon reasonable request.

\section{Ethics approval and consent to participate}

The study was approved by the ethics committee Ärztekammer Hamburg (WF-049/09). The work has been carried out in compliance with the Helsink Declaration. Informed consent: According to local laws (HmbKHG, §12,1), informed consent was not necessary.

\section{Consent for publication}

No individual person's data have been used in this manuscript

\section{Competing interests}

The authors declare they have no competing interests.

\section{Author details}

'Institute of Pathology, University Medical Center Hamburg-Eppendorf, Martinistr. 52, 20246 Hamburg, Germany. ${ }^{2}$ Department of Urology, University Medical Center Hamburg-Eppendorf, Hamburg, Germany.

Received: 15 March 2020 Accepted: 2 June 2020

Published online: 13 June 2020

\section{References}

1. Jonasch E, Gao J, Rathmell WK. Renal cell carcinoma. BMJ. 2014;349:g4797.

2. Wong MCS, Goggins WB, Yip BHK, Fung FDH, Leung C, Fang Y, Wong SYS, $\mathrm{Ng}$ CF. Incidence and mortality of kidney cancer: temporal patterns and global trends in 39 countries. Sci Rep. 2017;7:15698.

3. Rossi SH, Klatte T, Usher-Smith J, Stewart GD. Epidemiology and screening for renal cancer. World J Urol. 2018;36:1341-53.

4. Ljungberg B, Albiges L, Abu-Ghanem Y, Bensalah K, Dabestani S, FernandezPello S, Giles RH, Hofmann F, Hora M, Kuczyk MA, et al. European Association of Urology Guidelines on Renal Cell Carcinoma: The 2019 Update. Eur Urol. 2019(75):799-810.

5. Motzer RJ, Tannir NM, McDermott DF, Aren Frontera O, Melichar B, Choueiri TK, Plimack ER, Barthelemy P, Porta C, George S, et al. Nivolumab plus ipilimumab versus sunitinib in advanced renal-cell carcinoma. N Engl J Med. 2018:378:1277-90.

6. Choueiri TK, Halabi S, Sanford BL, Hahn O, Michaelson MD, Walsh MK, Feldman DR, Olencki T, Picus J, Small EJ, et al. Cabozantinib versus sunitinib as initial targeted therapy for patients with metastatic renal cell carcinoma of poor or intermediate risk: the Alliance A031203 CABOSUN Trial. J Clin Oncol. 2017;35:591-7.

7. Cerami E, Gao J, Dogrusoz U, Gross BE, Sumer SO, Aksoy BA, Jacobsen A, Byrne CJ, Heuer ML, Larsson E, et al. The cBio cancer genomics portal: an open platform for exploring multidimensional cancer genomics data. Cancer Discov. 2012;2:401-4.

8. Chen M, Yang Y, Liu Y, Chen C. The role of chromosome deletions in human cancers. Adv Exp Med Biol. 2018;1044:135-48.

9. Kluth M, Runte F, Barow P, Omari J, Abdelaziz ZM, Paustian L, Steurer S, Christina Tsourlakis M, Fisch M, Graefen M, et al. Concurrent deletion of $16 q 23$ and PTEN is an independent prognostic feature in prostate cancer. Int J Cancer. 2015;137:2354-63.

10. Lebok P, Roming M, Kluth M, Koop C, Ozden C, Taskin B, Hussein K, Lebeau A, Witzel I, Wolber L, et al. p16 overexpression and 9p21 deletion are linked to unfavorable tumor phenotype in breast cancer. Oncotarget. 2016;7: 81322-31.

11. Bohn BA, Mina S, Krohn A, Simon R, Kluth M, Harasimowicz S, Quaas A, Bockhorn M, Izbicki JR, Sauter G, et al. Altered PTEN function caused by deletion or gene disruption is associated with poor prognosis in rectal but not in colon cancer. Hum Pathol. 2013;44:1524-33.

12. Simon R, Richter J, Wagner U, Fijan A, Bruderer J, Schmid U, Ackermann D, Maurer R, Alund $G$, Knonagel $H$, et al. High-throughput tissue microarray analysis of 3p25 (RAF1) and 8p12 (FGFR1) copy number alterations in urinary bladder cancer. Cancer Res. 2001;61:4514-9.

13. Speicher MR, Schoell B, du Manoir S, Schrock E, Ried T, Cremer T, Storkel S, Kovacs A, Kovacs G. Specific loss of chromosomes 1, 2, 6, 10, 13, 17, and 21 in chromophobe renal cell carcinomas revealed by comparative genomic hybridization. Am J Pathol. 1994;145:356-64.

14. Brunelli M, Delahunt B, Gobbo S, Tardanico R, Eccher A, Bersani S, CossuRocca P, Parolini C, Balzarini P, Menestrina F, et al. Diagnostic usefulness of fluorescent cytogenetics in differentiating chromophobe renal cell carcinoma from renal oncocytoma: a validation study combining metaphase and interphase analyses. Am J Clin Pathol. 2010;133:116-26.

15. Yusenko MV, Kuiper RP, Boethe T, Ljungberg B, van Kessel AG, Kovacs G. High-resolution DNA copy number and gene expression analyses distinguish chromophobe renal cell carcinomas and renal oncocytomas. BMC Cancer. 2009;9:152.

16. Nagy A, Buzogany I, Kovacs G. Microsatellite allelotyping differentiates chromophobe renal cell carcinomas from renal oncocytomas and identifies new genetic changes. Histopathology. 2004:44:542-6.

17. Moch H, Cubilla AL, Humphrey PA, Reuter VE, Ulbright TM: The 2016 WHO classification of tumours of the urinary system and male genital organs-part A: renal, penile, and testicular tumours. Eur Urol 2016, 70:93-105.

18. Eichelberg C, Minner S, Isbarn H, Burandt E, Terracciano L, Moch H, Kell A Heuer R, Chun FK, Sauter G, et al. Prognostic value of alpha-methyl CoA racemase (AMACR) expression in renal cell carcinoma. World J Urol. 2013;31: $847-53$

19. Kononen J, Bubendorf L, Kallioniemi A, Barlund M, Schraml P, Leighton S, Torhorst J, Mihatsch MJ, Sauter G, Kallioniemi OP. Tissue microarrays for high-throughput molecular profiling of tumor specimens. Nat Med. 1998;4: 844-7.

20. Kluth M, Amschler NN, Galal R, Moller-Koop C, Barrow P, Tsourlakis MC, Jacobsen F, Hinsch A, Wittmer C, Steurer S, et al. Deletion of $8 \mathrm{p}$ is an independent prognostic parameter in prostate cancer. Oncotarget. 2017;8: 379-92.

21. Krohn A, Diedler T, Burkhardt L, Mayer PS, De Silva C, Meyer-Kornblum M, Kotschau D, Tennstedt P, Huang J, Gerhauser C, et al. Genomic deletion of PTEN is associated with tumor progression and early PSA recurrence in ERG fusion-positive and fusion-negative prostate cancer. The American journal of pathology. 2012;181:401-12.

22. Reutzel D, Mende M, Naumann S, Storkel S, Brenner W, Zabel B, Decker J. Genomic imbalances in 61 renal cancers from the proximal tubulus detected by comparative genomic hybridization. Cytogenet Cell Genet. 2001; 93:221-7.

23. Gronwald J, Baur AS, Holtgreve-Grez H, Jauch A, Mosimann F, Jichlinski P, Wauters JP, Cremer T, Guillou L. Chromosomal abnormalities in renal cell neoplasms associated with acquired renal cystic disease. A series studied by comparative genomic hybridization and fluorescence in situ hybridization. $J$ Pathol. 1999;187:308-12.

24. Contractor H, Zariwala M, Bugert P, Zeisler J, Kovacs G. Mutation of the p53 tumour suppressor gene occurs preferentially in the chromophobe type of renal cell tumour. J Pathol. 1997:181:136-9.

25. Kovacs A, Storkel S, Thoenes W, Kovacs G. Mitochondrial and chromosomal DNA alterations in human chromophobe renal cell carcinomas. J Pathol. 1992:167:273-7. 
26. Reiter RE, Anglard P, Liu S, Gnarra JR, Linehan WM. Chromosome 17p deletions and p53 mutations in renal cell carcinoma. Cancer Res. 1993;53: 3092-7.

27. Bi M, Zhao S, Said JW, Merino MJ, Adeniran AJ, Xie Z, Nawaf CB, Choi J, Belldegrun AS, Pantuck AJ, et al. Genomic characterization of sarcomatoid transformation in clear cell renal cell carcinoma. Proc Natl Acad Sci U S A. 2016;113:2170-5.

28. Brauch H, Pomer S, Hieronymus T, Schadt T, Lohrke H, Komitowski D. Genetic alterations in sporadic renal-cell carcinoma: molecular analyses of tumor suppressor gene harboring chromosomal regions $3 p, 5 q$, and $17 p$. World J Urol. 1994;12:162-8.

29. Kuczyk MA, Serth J, Bokemeyer C, Jonassen J, Arndt H, Paeslack U, Werner $\mathrm{M}$, Tan HK, Jonas U. Detection of p53 gene alteration in renal-cell cancer by micropreparation techniques of tumor specimens. Int J Cancer. 1995;64:399406

30. Uchida T, Wada C, Shitara T, Egawa S, Mashimo S, Koshiba K. Infrequent involvement of p53 mutations and loss of heterozygosity of 17p in the tumorigenesis of renal cell carcinoma. J Urol. 1993;150:1298-301.

31. Fogt F, Zhuang Z, Linehan WM, Merino MJ. Collecting duct carcinomas of the kidney: a comparative loss of heterozygosity study with clear cell rena cell carcinoma. Oncol Rep. 1998;5:923-6.

32. Morita R, Ishikawa J, Tsutsumi M, Hikiji K, Tsukada Y, Kamidono S, Maeda S, Nakamura Y. Allelotype of renal cell carcinoma. Cancer Res. 1991;51:820-3.

33. Ogawa O, Habuchi T, Kakehi Y, Koshiba M, Sugiyama T, Yoshida O. Allelic losses at chromosome 17p in human renal cell carcinoma are inversely related to allelic losses at chromosome 3p. Cancer Res. 1992;52:1881-5.

34. Presti JC Jr, Rao PH, Chen Q, Reuter VE, Li FP, Fair WR, Jhanwar SC. Histopathological, cytogenetic, and molecular characterization of renal cortical tumors. Cancer Res. 1991;51:1544-52.

35. Presti JC Jr, Reuter VE, Cordon-Cardo C, Mazumdar M, Fair WR, Jhanwar SC Allelic deletions in renal tumors: histopathological correlations. Cancer Res. 1993:53:5780-3.

36. Foster K, Crossey PA, Cairns P, Hetherington JW, Richards FM, Jones MH, Bentley E, Affara NA, Ferguson-Smith MA, Maher ER. Molecular genetic investigation of sporadic renal cell carcinoma: analysis of allele loss on chromosomes 3p, 5q, 11p, 17 and 22. Br J Cancer. 1994;69:230-4.

37. Hoglund M, Gisselsson D, Mandahl N, Johansson B, Mertens F, Mitelman F, Sall T. Multivariate analyses of genomic imbalances in solid tumors reveal distinct and converging pathways of karyotypic evolution. Genes Chromosomes Cancer. 2001;31:156-71.

38. Chen M, Ye Y, Yang H, Tamboli P, Matin S, Tannir NM, Wood CG, Gu J, Wu $X$. Genome-wide profiling of chromosomal alterations in renal cell carcinoma using high-density single nucleotide polymorphism arrays. Int $\rfloor$ Cancer. 2009:125:2342-8.

39. Sugimura J, Tamura G, Suzuki Y, Fujioka T. Allelic loss on chromosomes 3p, $5 q$ and 17p in renal cell carcinomas. Pathol Int. 1997:47:79-83.

40. Thrash-Bingham CA, Greenberg RE, Howard S, Bruzel A, Bremer M, Goll A, Salazar H, Freed JJ, Tartof KD. Comprehensive allelotyping of human renal cell carcinomas using microsatellite DNA probes. Proc Natl Acad Sci U S A. 1995;92:2854-8.

41. Morita R, Saito S, Ishikawa J, Ogawa O, Yoshida O, Yamakawa K, Nakamura Y. Common regions of deletion on chromosomes $5 q, 6 q$, and $10 q$ in renal cell carcinoma. Cancer Res. 1991:51:5817-20.

42. Malouf GG, Monzon FA, Couturier J, Molinie V, Escudier B, Camparo P, Su X, Yao H, Tamboli P, Lopez-Terrada D, et al. Genomic heterogeneity of translocation renal cell carcinoma. Clin Cancer Res. 2013;19:4673-84.

43. Perrino CM, Hucthagowder V, Evenson M, Kulkarni S, Humphrey PA. Genetic alterations in renal cell carcinoma with rhabdoid differentiation. Hum Pathol. 2015:46:9-16.

44. Dijkhuizen T, Van den Berg E, Van den Berg A, Storkel S, De Jong B, Seitz G, Henn W. Chromosomal findings and p53-mutation analysis in chromophilic renal-cell carcinomas. Int J Cancer. 1996;68:47-50.

45. Yoshioka K, Nakamura S. Chromosome 9 and 17 aberrations and p53 gene deletion detected by fluorescence in situ hybridization in renal-cell carcinoma. Mol Urol. 2001;5:11-7.

46. Li VD, Li KH, Li JT. TP53 mutations as potential prognostic markers for specific cancers: analysis of data from The Cancer Genome Atlas and the International Agency for Research on Cancer TP53 Database. J Cancer Res Clin Oncol. 2019;145:625-36.

47. Kroeger N, Klatte T, Chamie K, Rao PN, Birkhauser FD, Sonn GA, Riss J, Kabbinavar FF, Belldegrun AS, Pantuck AJ. Deletions of chromosomes 3p and $14 q$ molecularly subclassify clear cell renal cell carcinoma. Cancer. 2013; 119:1547-54.

48. Monzon FA, Alvarez K, Peterson L, Truong L, Amato RJ, Hernandez-McClain J, Tannir N, Parwani AV, Jonasch E. Chromosome 14q loss defines a molecular subtype of clear-cell renal cell carcinoma associated with poor prognosis. Mod Pathol. 2011;24:1470-9.

49. Eichenauer T, Bannenberg DC, Kluth M, Wittmer C, Buscheck F, Moller K, Dum D, Fraune C, Hube-Magg C, Moller-Koop C, et al. 8p deletions in renal cell carcinoma are associated with unfavorable tumor features and poor overall survival. Urol Oncol. 2020;38:43 e13-20.

50. Eichenauer $T$, Simmendinger $L$, Kluth $M$, Chirico V, Luebke AM, Hoflmayer D, Hinsch A, Jacobsen F, Hube-Magg C, Moller-Koop C, et al. Chromosomal deletion of 9p21 is linked to poor patient prognosis in papillary and clear cell kidney cancer. Urol Oncol. 2020;38(6):605.e1.

51. Lichner Z, Scorilas A, White NM, Girgis AH, Rotstein L, Wiegand KC, Latif A Chow C, Huntsman D, Yousef GM. The chromatin remodeling gene ARID1A is a new prognostic marker in clear cell renal cell carcinoma. Am J Pathol. 2013;182:1163-70

52. de Oliveira D, Dall'Oglio MF, Reis ST, Zerati M, Souza IC, Leite KR, Srougi M. Chromosome $9 p$ deletions are an independent predictor of tumor progression following nephrectomy in patients with localized clear cell renal cell carcinoma. Urol Oncol. 2014:32:601-6.

53. Jiang F, Richter J, Schraml P, Bubendorf L, Gasser T, Sauter G, Mihatsch MJ, Moch H. Chromosomal imbalances in papillary renal cell carcinoma: genetic differences between histological subtypes. Am J Pathol. 1998;153:1467-73.

54. Klatte T, Rao PN, de Martino M, LaRochelle J, Shuch B, Zomorodian N, Said J, Kabbinavar FF, Belldegrun AS, Pantuck AJ. Cytogenetic profile predicts prognosis of patients with clear cell renal cell carcinoma. J Clin Oncol. 2009: 27:746-53.

55. Yap NY, Rajandram R, Ng KL, Pailoor J, Fadzli A, Gobe GC. Genetic and chromosomal aberrations and their clinical significance in renal neoplasms. Biomed Res Int. 2015;2015:476508.

56. Buscheck F, Fraune C, Kluth M, Lennartz M, Simon R, Hube-Magg C, Morlock C, Barbieri S, Wahl C, Eichelberg C, et al. A non-diploid DNA status is linked to poor prognosis in renal cell cancer. World J Urol. 2020.

57. Mathieu J, Detraux D, Kuppers D, Wang Y, Cavanaugh C, Sidhu S, Levy S, Robitaille AM, Ferreccio A, Bottorff T, et al. Folliculin regulates mTORC1/2 and WNT pathways in early human pluripotency. Nat Commun. 2019;10:632.

58. Pavlovich CP, Walther MM, Eyler RA, Hewitt SM, Zbar B, Linehan WM, Merino MJ. Renal tumors in the Birt-Hogg-Dube syndrome. Am J Surg Pathol. 2002;26:1542-52

\section{Publisher's Note}

Springer Nature remains neutral with regard to jurisdictional claims in published maps and institutional affiliations.

Ready to submit your research? Choose BMC and benefit from:

- fast, convenient online submission

- thorough peer review by experienced researchers in your field

- rapid publication on acceptance

- support for research data, including large and complex data types

- gold Open Access which fosters wider collaboration and increased citations

- maximum visibility for your research: over $100 \mathrm{M}$ website views per year

At BMC, research is always in progress.

Learn more biomedcentral.com/submissions 